\title{
POU5F1B wt Allele
}

National Cancer Institute

\section{Source}

National Cancer Institute. POU5F1B wt Allele. NCI Thesaurus. Code C113313.

Human POU5F1B wild-type allele is located in the vicinity of 8q24.21 and is approximately $6 \mathrm{~kb}$ in length. This allele, which encodes putative POU domain, class 5, transcription factor 1B protein, plays a role in the regulation of transcription. 